\title{
Small Intestine Cancer pT3 TNM Finding v7
}

National Cancer Institute

\section{Source}

National Cancer Institute. Small Intestine Cancer pT3 TNM Finding v7. NCI Thesaurus.

Code C89872.

Small intestine cancer with tumor invading through the muscularis propria into the subserosa or into the nonperitonealized perimuscular tissue (mesentery or retroperitoneum) with extension $2 \mathrm{~cm}$ or less. Note: The nonperitonealized perimuscular tissue is, for jejunum and ileum, part of the mesentery and, for duodenum in areas where serosa is lacking, part of the interface with the pancreas. (from AJCC 7th Ed.) 